\title{
THE IMPACT OF SEAWEED FARMING ON THE PHYTOPLANKTON COMMUNITY STRUCTURE
}

\author{
Parman Parakkasi ${ }^{1}$, Chair Rani ${ }^{2}$, Rajuddin Syamsuddin ${ }^{3}$, Najamuddin ${ }^{3}$, Rahmadi Tambaru ${ }^{2 *}$ \\ Submitted: January 14, 2020 Accapted: February 25, 2020
}

\author{
${ }^{1}$ Doctoral Program in Fishery Sciences, Faculty of Marine Science and Fisheries, University of Hasanuddin \\ ${ }^{2}$ Department of Marine Science, Faculty of Marine Science and Fisheries, University of Hasanuddin \\ ${ }^{3}$ Department of Fisheries, Faculty of Marine Science and Fisheries, University of Hasanuddin \\ Coresponding Author: \\ *Rahmadi Tambaru \\ Email: aditbr69@yahoo.com
}

\begin{abstract}
This study was aimed to analyze the impact of seaweed farming on changes in the structure of phytoplankton communities on various ecosystems and their relationship with environmental factors. The study was conducted in May-October 2017 in the waters of Karampuang Island, Mamuju Regency. Plankton samples were collectedfromthreecultivationareas, namely areas with sandy bottom (control), seagrass beds, and coral reefs. In each area, three media were placed with a longline system, size $40 \mathrm{x}$ $30 \mathrm{~m} 2$ (as replication). Sampling was carried out at the beginning before initiation of the cultivation and every two weeks after cultivation was started for 42 days. Phytoplankton sampling and measurement of environmental factors were carried out at fivesamplingpoints representing the cultivation areas. In sandy areas, sampling was also applied in areas outside the cultivation at a distance of $25 \mathrm{~m}$ and $50 \mathrm{~m}$. Variance analysis was used to analyze differences in the species number and abundance of phytoplankton. Ecological indices was used to test phytoplankton biodiversity. PCA was used to analyze its relationship with environmental factors. Differences in the species number and abundance of phytoplankton between farming areas according to temporal scale were found. The high number and speciesabundance of phytoplankton were found in seagrass areas and significantly different from coral reefs and sandy area. Seaweed farming at the beginning of the farming period showed a positive impact by increasing the number of species and abundance of phytoplankton, but then decreased after entering Week 4-Week 6, along with the occurrence of ice-ice disease on the seaweed. Diversity index value was classified as medium with high equality without the dominance of particular species. The high number of species and abundance of phytoplankton occured at second weeks in all cultivation areas which are characterized by abundance of zooplankton with environmental characteristics, i.e. high DO and low PO4, NO3, andDOM.
\end{abstract}

Keywords: Impact, seaweed culture, phytoplankton, Karampuang Island

\section{INTRODUCTION}

Indonesia as an archipelagic country has abundant potential for the development of seaweed commodities (Kadi, 2004; Putri, et al., 2014; Hikmah, 2015). Development activities have been implemented in all Indnesianwaters from Aceh to Papua (Bappenas, 2014a). To achieve production targets, the government seeks to develop a seaweed development program by building cooperation between relevant institutions and ministries as well as business actors such as farmers, traders, exporters, and processing industries, including bank and non-bank financial institutions (Kusumastanto, 2008; Rachbini, et al., 2011).

In order to support the above targets, it is necessary to carry out continuous research, especially related to the prospects of developing seaweed cultivation. The research is expected to be useful as input in the formulation of a national and sustainable seaweed industry development strategy in the future. In addition, research results may increase demand on seaweeds by consumer countries (Priono, 2013).

In the future, it is predicted that seaweed cultivation will play an important role in providing world food consumption (Dwiyitno, 2011 and Bappenas, 2014b). Through these efforts, resources in the form of food and feed are expected to be supplied and support the availability of food and feed nationally (Wagiman and
Ainuri, 2015; Talib, 2018). The results can also be processed into environmentally friendly energy raw materials, antioxidants, probiotics or prebiotic properties while providing environmental and economic servicess (Radulovich, et.al., 2015).

In terms of contribution to the environment, seaweed cultivation in fact has a positive impact on the aquatic environment and increases the potential of fishery resources. Seaweed cultivation may produce ecological benefits by creating habitats and providing food sources for the growth of fish and other organisms (Sievanen et al., 2005; Faisal, et al., 2013; Priono, 2013). In addition, the seaweed cultivation area creates a calm and protected atmosphere (Syafiuddin, 2008; Burdames and Ngangi, 2014), thus stimulating organisms such as plankton and larvae of other marine biota to grow and develop. Eventually, it will give effect to the distribution and biodiversity of phytoplankton. Therefore, research regarding determination of the the suitablet location is an important factor in the success of seagrass cultivation. Likewise, adjustments to water conditions must be appropriate with the cultivation method used (Neksidin, 2013).

Several studies examining biodiversity of phytoplankton in the vicinity of seaweed cultivation have been conducted, such as by Akib et al. (2015) in 
the District of Selayar Archipelago and Apriliyanti (2018) in the District of Bantaeng. These studiesonly looked at the species of phytoplankton and the suitability of water quality for seaweed cultivation. No information has been found that discusses the impact of seaweed farming activities in various areas of cultivation (ecosystems), particularly on the phytoplankton community and abundance of phytoplankton at various locations and times of observation as well as their relationship to the environmental factors.

\section{MATERIALS AND METHODS}

The study was conducted from May to October 2017 in the waters around Karampuang Island, Mamuju Regency, West Sulawesi Province (Figure 1). These waters were chosen because theirdeeperpart facing to the mainland is protected by the island. Physically, it is possible to operate seaweed culture.
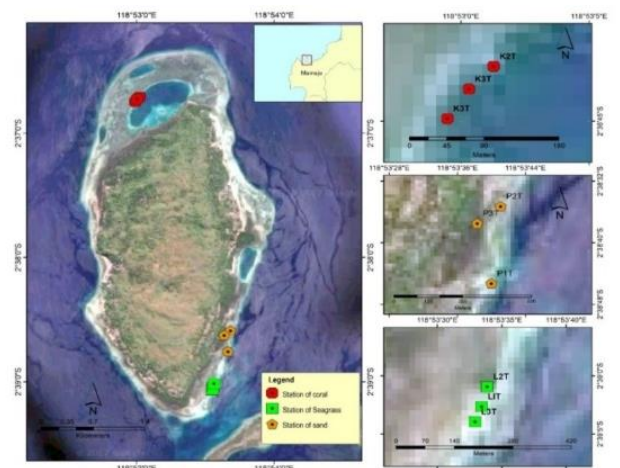

Figure1. Location of Plankton Sample Collection in Coastal Areas of Mamuju Regency

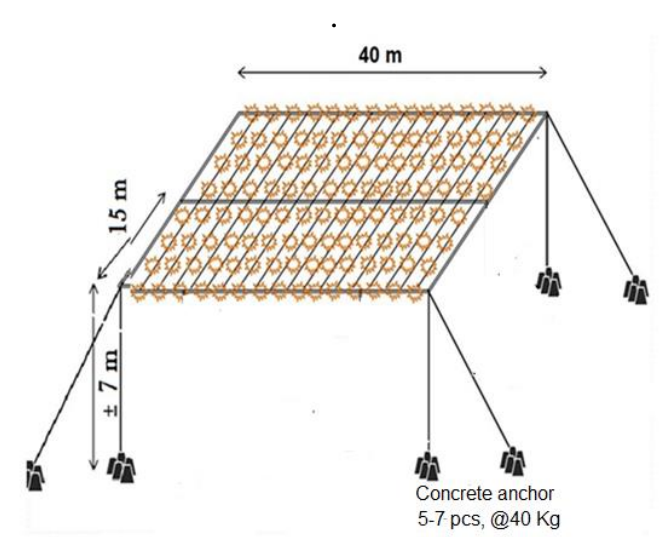

Figure 2. Media of Seaweed Culture with Longline System used in the Study

\section{Media of Seaweed Culture}

The seaweed cultivation method used in this studywas the longline method. One unit of cultivation media with the technology applied in this study (Figure 2),deployed as many as 160 lines with a length of each linewas $15 \mathrm{~m}$ and the distance between twolines as wide as $50 \mathrm{~cm}$. The binding distance of the seedlings was 20 $\mathrm{cm}$ wide, so in one linewas bound to 75 seeds. The weight of the seaweed seeds used was approximately 100 grams. The total number of ties in one unit of seaweed cultivation was 12,000 seedlings. Furthermore, the seaweed cultivation unit was moved to the location of coral, seagrass and sand ecosystems. In each area (sand, seagrass and coral reefs),three units were placed as replicatesSample Collection

Plankton sampling was carried out at three locations of seaweed cultivation. These three locations were Sandy Bottom (Control), Seagrass Bed, and Coral Reef. Plankton sampling were carried out at five sampling points that have been determined at each location, namely the middle and at each corner of the cultivation cages. Specifically for the comparison of the average number of species and abundance of plankton based on distances, testing was only done at the Sand location at four placement points, i.e.: 1) the center of the cultivation area; 2 ) the edge of the cultivation area; 3 ) a distance of $25 \mathrm{~m}$ from the cultivation area; and 4) distance of $50 \mathrm{~m}$ from the cultivation area.

Every two weeks, plankton samples were collected by filtering water using planktonnet no. 25 . The results of the water filter were put in a bottle of samples that have been labeled and added 2\% Lugol solution as much as 8-10 drops. Plankton samples were then analyzed using a microscope to determine their number and abundance. Identification of plankton species was carried out using a number of standardized identification books such as Davis (1955), Yamaji (1979), and Tomas (1997). The technique for calculating of phytoplankton cell abundance was sweeping (census) using Sedwick Rafter Cell (SRC) (APHA, 1989). For the calculation of biodiversity, the Shannon-Wiener diversity and evenness index equation was used (Krebs, 1989).

Water quality variables at three locations of seaweed cultivation locations were monitoredsimultaneously with plankton sampling. Water sampling was carried out at five points within the cultivation area (center and angles). Water quality parameters were measured directly in the field (in situ) include temperature, $\mathrm{pH}$, salinity, and DO. The content of nitrate, phosphate, and total organic matter (TOM) was conducted by carrying surface water samples from each seaweed cultivation location, which was then analyzed in the laboratory

\section{Data Analysis}

Differences in average values of the number and species abundance of plankton among the placement location of cultivation per time of measurement were analyzed using ANOVA to study the impact of culture on biodiversity and abundance of plankton. Similar testing was also done at the sandy location to test the average values of the number of species and the abundance of plankton on a four- point placement. The dynamics of the phytoplankton biodiversity on a weekly basis were analyzed descriptively based on line graphs for their ecological index values (diversity 
index, evenness index and dominance index). Spatialtemporal distribution of phytoplankton and their association with environmental factors in the three locations where seaweed cultivation is placed were analyzed by multivariate analysis: Principal Component Analysis Technique, PCA (Ludwig and Reynolds, 1988) with assistance of the XL-Stat software.

\section{RESULTS AND DISCUSSION}

\section{Phytoplankton Composition and Abundance}

During the study, four phytoplankton classes were found dispersed in all locations of seaweed cultivation. The classes were Bacillariophyceae, Cyanophyceae, Dinophyceae, and Fragilariophyceae

Table 1. Average abundance of phytoplankton based on cultivation areas in different observation time

\begin{tabular}{|c|c|c|c|c|c|c|c|c|c|c|c|}
\hline \multicolumn{4}{|c|}{ Time of Observation (W=Week) } & \multicolumn{4}{|c|}{ Class of Phytoplankton } & & & & \\
\hline \multicolumn{2}{|c|}{ Week (W) Location } & \multicolumn{2}{|c|}{ Bacillarophyceae } & \multicolumn{2}{|c|}{ Dinophyceae } & \multicolumn{2}{|c|}{ Cyanophyceae } & \multicolumn{2}{|c|}{ Fragilariophyceae } & \multicolumn{2}{|c|}{ Total } \\
\hline & & $\begin{array}{c}\text { Number of } \\
\text { Species }\end{array}$ & $\begin{array}{c}\text { Anundance } \\
(\mathrm{cel} / \mathrm{L})\end{array}$ & $\begin{array}{c}\text { Number of } \\
\text { Species }\end{array}$ & $\begin{array}{c}\text { Anundance } \\
(\mathrm{cel} / \mathrm{L})\end{array}$ & $\begin{array}{c}\text { Number of } \\
\text { Species }\end{array}$ & $\begin{array}{c}\text { Anundance } \\
(\mathrm{cel} / \mathrm{L})\end{array}$ & $\begin{array}{c}\text { Number of } \\
\text { Species }\end{array}$ & $\begin{array}{c}\text { Anundance } \\
(\mathrm{cel} / \mathrm{L})\end{array}$ & $\begin{array}{c}\text { Number of } \\
\text { Species }\end{array}$ & $\begin{array}{c}\text { Anundance } \\
(\mathrm{cel} / \mathrm{L})\end{array}$ \\
\hline \multirow[t]{3}{*}{$\mathrm{W}-0$} & Seagrass & 20 & 70889 & 3 & 8889 & 3 & 79556 & 1 & 13333 & 27 & 172667 \\
\hline & Coral Reef & 12 & 27111 & 3 & 4044 & 3 & 61333 & 1 & 3333 & 19 & 95822 \\
\hline & Sand & 14 & 25778 & 4 & 2667 & 3 & 98667 & 1 & 4667 & 22 & 131778 \\
\hline \multirow[t]{3}{*}{$\mathrm{W}-2$} & Seagrass & 20 & 156444 & 3 & 4667 & 3 & 21111 & 1 & 5778 & 27 & 188000 \\
\hline & Coral Reef & 15 & 272011 & 2 & 4222 & 4 & 22000 & 1 & 3111 & 22 & 301344 \\
\hline & Sand & 19 & 202889 & 2 & 3333 & 3 & 31333 & 1 & 11333 & 25 & 248889 \\
\hline \multirow[t]{3}{*}{ W-4 } & Seagrass & 19 & 136000 & 3 & 8889 & 3 & 50889 & 1 & 5333 & 26 & 201111 \\
\hline & Coral Reef & 11 & 28222 & 3 & 4667 & 4 & 28222 & 1 & 5111 & 19 & 66223 \\
\hline & Sand & 11 & 33111 & 1 & 1556 & 2 & 10667 & 1 & 4889 & 15 & 50222 \\
\hline \multirow[t]{3}{*}{ W-6 } & Seagrass & 16 & 32889 & 4 & 6889 & 4 & 33333 & 1 & 2889 & 25 & 76000 \\
\hline & Coral Reef & 13 & 41556 & 3 & 4889 & 2 & 46889 & 1 & 4889 & 19 & 98222 \\
\hline & Sand & 14 & 33526 & 3 & 2889 & 2 & 32444 & 1 & 8222 & 19 & 77111 \\
\hline
\end{tabular}

Based on the number and abundance of phytoplankton identified, Bacillariophyceae is a class that has a higher number and abundance of phytoplankton when compared with other phytoplankton classes. Some genera that always occur during the research include Chaetoceros and Navicula from the Class Bacillariophyceae, Oscillatoria from the Class Cyanophyceae, and Synedra from the Class Fragilariophyceae. The number of phytoplankton species based on the location of seaweed cultivation, recorded as many as 27 species found at seagrass locations and 20 species each found at the location of Coral Reef and Sand (Figure 2). The average number of species at seagrass locations was found to be higher compared to other locations. For the abundance of phytoplankton based on seaweed cultivation locations, the average abundance of phytoplankton at seagrass locations was found at 159167 cells/L, then the location of Coral Reefs was 140403 cells/L and location of Sand were found to be 127000 cells/L (Table 1 and Figure $3)$. From the results of the enumeration, seagrass locations have a higher average abundance when compared to other locations.

Seaweed cultivation may create new niche and establish new food chains in the water column, both directly and indirectly on the life of other organisms. The presence of herbivorous fishes that often harvest seaweed (Syarqawi et al., 2017) is a direct impact of the activity. The calmer or protected waters (Syafiuddin, 2008; Burdames and Ngangi, 2014) may attract microsized biota such as plankton and larvae of marine organisms to grow and develop are other indirect impacts. The situation created has an effect on other large-sized organisms foraging in the area of cultivation (Sievanen et al., 2005).
The Bacillariophyceae is a class that has a higher number and abundance of phytoplankton when compared to other phytoplankton classes. The high number and abundance of phytoplankton in the Class Bacillariophyceae is due to the species of phytoplankton in this class, generally having the ability to respond to changes in the environment condition so that they may survive when compared with phytoplankton species from other classes (Amin, et al., 2012; Armbrust, 2012; Collins et al., 2014). According to Arinardi et al. (1997), the species of phytoplankton in the Class Bacillariophyceae has the ability to adapt to the environment so that the species in this class are often found in a variety of different environmental conditions (cosmopolitan in nature). In addition, the species in the Class Bacillariophyceae generally have the ability to reproduce quickly (Armbrust and Galindo, 2001; Chepurnov et al., 2008; Armbrust, 2012) when compared with phytoplankton species from other classes. For this reason, they are classified as major producers and contributors of organic material in marine waters, have a wide distribution and can be found in various types of habitats and seasons (Mochizuki et al., 2002). This class tends to dominate open sea, beach and estuarine waters (Tomas, 1997).

Some genera that always occur during the study include Chaetoceros and Navicula from the Class Bacillariophyceae and Oscillatoria from the Class Cyanophyceae and Synedra from the Class Fragilariophyceae. They are the genera that characterize phytoplankton in the marine coastal area (Pandiyarajan et al., 2014). Their presence, especially phytoplankton species from the Classes Bacillariophyceae and Cyanophyceae, is an indication that the waters are still classified as good even though 
parameters such as nutrients (mainly nitrates and phosphates) are not in optimal concentration (Nontji, 2008).

\section{Changes in Phytoplankton Species}

Changes in the phytoplankton speciesintended are changes in the number and abundance of phytoplankton among locations at each measurement time. Based on the One-Way ANOVA analysis, there are differences in the number of species based on location at the time of initial observation ( $p<0.05)$. From the results of further tests using the SNK method, seagrass locations have a greater number of species when compared to the location of Coral Reefs and Sand, while the locations of Coral Reefs and Sand are no different ( $p>0.05)$ (Figure 3).

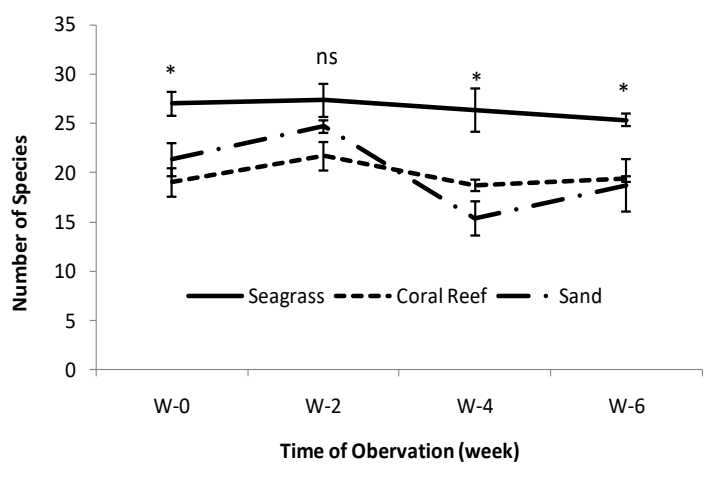

Figure3. Average number of species of phytoplankton based on cultivation areas in different observation time

At the time of Week-2 observation, the results were different from the time of the initial observation, the number of species at the three locations was considered to be the same $(p>0.05)$. At the time of Week-4 observation, the number of phytoplankton species at the three locations was also found to be different ( $p<0.05$ ), the number of phytoplankton species at the seagrass location was different from the location of Sand and Coral Reef, while the location of Sand and Coral Reef was the same ( $p>0.05)$.

The last observation is the Week-6 observation time. The results of the analysis at the time of this observation were the same as the Week-4 observations, the number of phytoplankton species in the seagrass site still showed differences with the location of Sand and Coral Reefs $(\mathrm{p}<0.05)$. Even though there was an increase in the number of phytoplankton species at the Sand location, the number of phytoplankton species between the Sand and Coral Reef locations was still considered the same ( $p>0.05)$.

Furthermore, the impact of seaweed cultivation on differences in phytoplankton abundance between locations at each time of measurement showed that the average abundance of phytoplankton at the time of the initial observation was found to be different between locations of cultivation ( $p<0.05$ ). Seagrass locations have a higher abundance when compared to the location of Coral and Sand, while the locations of Coral and Sand are considered to be the same ( $p>0.05)$. At the time of Week-2 observation, the results of the OneWay ANOVA analysis of the average abundance of phytoplankton did not show differences by location (Figure 4). The results of the analysis showed that the average abundance of phytoplankton at the time of Week-2 observation had an abundance that was considered uniform at all three locations ( $\mathrm{p}>0.05)$.

In general, the pattern of changes in the number and abundance of phytoplankton at the three seaweed cultivation locations was observed to be the same during the study (Figures 2 and 3). For example, during Week-2 observation, the number of species and abundance of phytoplankton increased at the three cultivation locations, then decreased at the time of Week-4 observation. More specifically, the impact of seaweed cultivation on changes in the number and abundance of phytoplankton in the three cultivation locations may be examined by looking at the results of the ANOVA analysis (discussion of section 3.2). Based on the results of the analysis, changes in the number and abundance of phytoplankton in the three seaweed cultivation locations are different from one location to another based on the time of observation. Seaweed cultivation negatively affects changes in the number and abundance of phytoplankton in the Coral and Sand locations at the time of Week-4 observation, while in seagrass sites at the time of observation of Week-4 to Week-6 (Figures 2 and 3). At the time of Initial and Week-2 observations, the negative influence of seaweed cultivation was not yet identified.

Reasons that may be given in explaining the above results can be related to seaweed growth based on observation time. At the initial observation up to Week2 , seaweed that was cultivated was still not stable in absorbing nutrients (the initial stages of cultivation) even though the growth data of seaweed was detected quite high. The presence of seaweed instability in absorbing nutrients in the initial stages of the cultivation causes nutrients, especially phosphate available, is quite high (Seagrass $=0.053 \mathrm{mg} / \mathrm{L}$; Coral reef $=0.067 \mathrm{mg} / \mathrm{L}$; and Sand $=0.045 \mathrm{mg} / \mathrm{L}$ ) at the seaweed cultivation locations (Appendix 1). Phosphate concentrations in the three cultivation locations are high in the fertile category. According to Effendi (2003), phosphate concentration ranges between 0.051$0.1 \mathrm{mg} /$ Liter including fertile waters. This causes phytoplankton to grow well.

The above events can be observed particularly at the location of the Coral Reef and Sand. It was noted that the number and abundance of phytoplankton at the two locations actually experienced a fairly high increase at the time of Week-2 observation. This is different from what happens at the location of seagrasses. The phosphate which is also sufficient is not only used by phytoplankton but also absorbed by the seagrass itself to grow and develop. As a result, the number and abundance of phytoplankton do not increase rapidly, as 
in the case ofcoral and sand sites. Based on that, the analysis of the amount and abundance of phytoplankton at the seagrass location is the same $(p>0.05)$ as the location of the Coral Reef and Sand.

Different things occur when entering the Week-4 observation time. The number and species of phytoplankton abundance in general decreased based on the location of cultivation. This happened simultaneously with the occurrence of ice-ice attacks on seaweed cultivation. The calm waters and maximum irradiation followed by rain are thought to be the cause of the emergence of the ice-ice disease. It turned out that this condition also affected the phytoplankton community, namely the number and abundance of phytoplankton in general decreased (Figures 2 and 3). This phenomenon continued until the time of Week- 6 observation. The value of environmental parameters in the ice-ice event increased in values such as NO3 and TOM, while the temperature, $\mathrm{pH}$, and salinity decreased especially in the 4th week (Table 3). In the ice-ice event, a lot of seaweed thallus decays and decays and becomes organic material and eventually it will be broken down into nutrients so that the measured DOM and NO3 content increases.

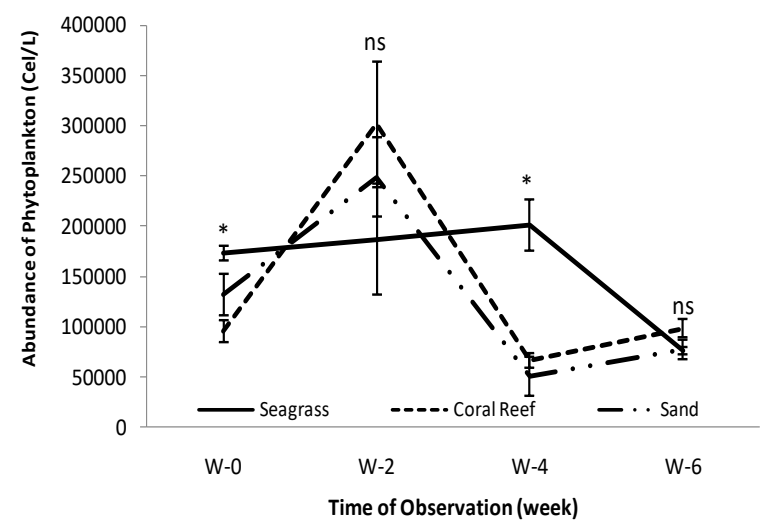

Figure4. Average abundance of phytoplankton based on cultivation areas in different observation time

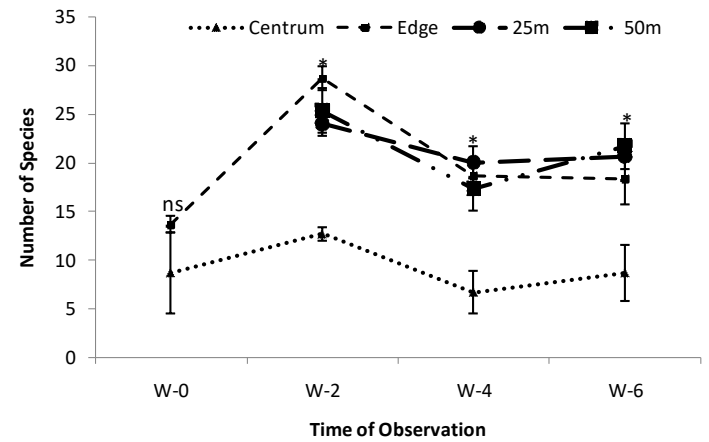

Figure5. Average number of species of phytoplankton based on distance from the cultivation area based on observation time in sand substrate area.

Then, the average abundance of phytoplankton at the time of Week-4 observation showed that the abundance of phytoplankton at the seagrass location was different from the location of the Coral Reef and Sand, whereas, the abundance of phytoplankton at the Sand and Coral Reef location was not different. with the Week-4 observation time (Figure 4)

Testing the impact of Seaweed cultivation on differences in the average number and abundance of phytoplankton based on the distance from the cultivation area according to the time of observation in areas with sand substrate is shown in Figures 5 and 6.

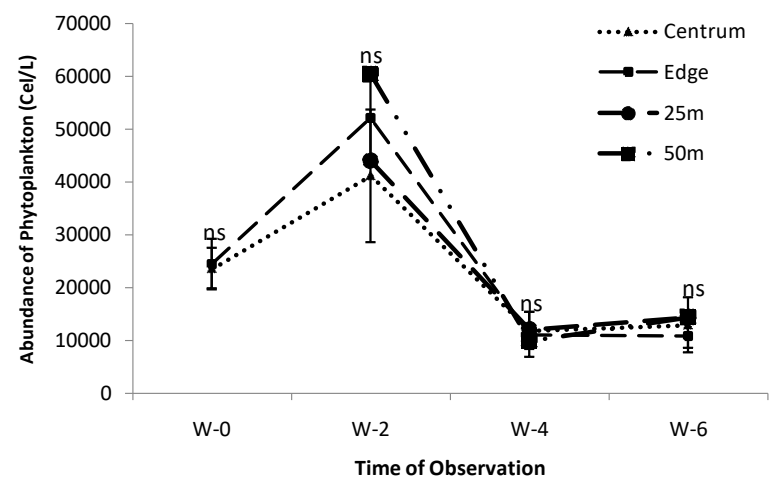

Figure 6. Average abundance of phytoplankton based on distance from the cultivation area based on observation time in sand substrate area

In Figure 5 and 6, it can be observed that the pattern of phytoplankton abundance and number of species increased in the 2 nd week compared to initial condition before the cultivation is started (the beginning of the study) and decreased in the next week as the ice-ice events occurred at the cultivated seaweed. The results of the analysis of variance showed that the number of different species of phytoplankton $(p<0.05)$ between the observation points at the time of observation Week2 to Week-6. However, in terms of phytoplankton abundance, it did not show significant differences ( $p>$ 0.05 ). The center or middle observation point shows a lower number of species and is different from the other three points (edge, $25 \mathrm{~m}$, and $50 \mathrm{~m}$ ), but the three observation points are not different.

Another impact that may be explored is the distance from the cultivation area in the sandy area. The pattern of changes in the number of species and abundance of plankton is also observed decreasing after entering the 4 th week at each distance (middle, edge, $25 \mathrm{~m}$, and $50 \mathrm{~m}$ from the cultivation area). It is also suspected by the decrease in environmental conditions when ice-ice occurs. In terms of abundance, it is not affected by distance, but the number of species is affected (Figures 4 and 5). The lowest number of species is in the middle and highest in the edge of the cultivation area. The number of species at the edges and at distances of $25 \mathrm{~m}$ and 50m does not differ (Figure 6).

\section{Phytoplankton Biodiversity}

Values of the diversity index $\left(\mathrm{H}^{\prime}\right)$ of each cultivation location (Seagrass, Coral Reef, and Sand) during the study ranged from 1.92-2.46, 1.42-1.72, and 1.36-2.15, respectively (Table 2 ). 
Table 2.Biodiversitas of the phytoplankton based on the ecological index values

\begin{tabular}{lllll}
\hline $\begin{array}{l}\text { Cultivation } \\
\text { Location }\end{array}$ & $\begin{array}{l}\text { Observation } \\
\text { Time }\end{array}$ & Average Ecological Index Values & \\
\hline & & $\begin{array}{l}\text { Diversity Index } \\
\left(\mathrm{H}^{\prime}\right)\end{array}$ & $\begin{array}{l}\text { Evennes Index } \\
(\mathrm{E})\end{array}$ & $\begin{array}{l}\text { Dominance } \\
\text { Index } \\
(\mathrm{D})\end{array}$ \\
\hline Seagrass & 2.29 & 0.69 & 0.22 \\
& Initial & 2.15 & 0.65 & 0.27 \\
& W2 & 1.92 & 0.59 & 0.28 \\
& W4 & 2.46 & 0.76 & 0.17 \\
\hline W6 & Range & $1.92-2.46$ & $0.59-0.76$ & $0.17-0.28$ \\
\hline Coral Reef & Initial & 1.67 & 0.57 & 0.37 \\
& W2 & 1.42 & 0.46 & 0.45 \\
& W4 & 2.31 & 0.80 & 0.15 \\
& W6 & 1.72 & 0.58 & 0.31 \\
\hline Sand & Range & $1.42-1.72$ & $0.46-0.80$ & $0.15-0.45$ \\
& Initial & 1.36 & 0.44 & 0.51 \\
& W2 & 1.78 & 0.53 & 0.35 \\
& W4 & 2.11 & 0.71 & 0.26 \\
& W6 & 2.15 & 0.70 & 0.21 \\
\hline
\end{tabular}

From this index value, it can be explained that the index of phytoplankton diversity at three cultivation locations during the study is included in the medium category (1 $\leq \mathrm{H}^{\prime} 3$ ) (Krebs, 1989; Masson, 1981). Furthermore, the range of evenness index values $(\mathrm{E})$ at each cultivation location (Seagrass, Coral Reef, and Sand) were 0.59$0.76,0.58-0.80$, and $0.44-0.71$, respectively. Each index value indicates that phytoplankton in general have a relatively high evenness index.

Table 2 shows the results of the analysis of the ecological index (diversity index and evenness index) which illustrates the dynamics of biodiversity of phytoplankton species in various Seaweed cultivation locations. In the table, the diversity index values $\left(\mathrm{H}^{\prime}\right)$ of each cultivation location (Seagrass, Coral Reef, and Sand) were included in the medium category ( $1 \leq \mathrm{H}$ ' 3 ) (Krebs, 1989; Masson, 1981). Based on that category, it can be explained that the phytoplankton species are not in optimal conditions for growth and development. The reason for this is due to

environmental factors such as phosphate not in the range of values that correspond to the optimal growth and development of phytoplankton (Appendix 1). Starting from the time of Week- 4 observation, phosphate concentration continues to decline so it cannot support its growth. Furthermore, the range of evenness index values (E) at each cultivation location (Seagrass, Coral Reef, and Sand) shows that phytoplankton species generally have a high evenness index (evenness index values generally are more than 0.5 or close to 1 , Table 2). Evenness index (E) is categorized high if the value is close to 1 , on the contrary,it is considered as low if the value is close to 0 (Odum, 1998). That means that the species of phytoplankton during the study have high evenness in the sense that the distribution of individuals of each species is considered to be dispersed in uniform assemblage. Then, the value of the dominance index also has a value between $0-1$. The smaller the index value indicates that there is no dominating species and vice versa. Table 2 in general shows a dominance index value close to 0 . This means that during the study there were no species dominating. The three study sites were still feasible and in accordance with the growth of various species of phytoplankton despite some environmental factors were not in optimal condition.

\section{Linkage of phytoplankton with the environmental factors}

The relationship between the number of plankton species and abundance with environmental factors (physical-chemical and biological factors) in the three locations of seaweed cultivation based on the observation time was analyzed using PCA analysis (Table 3 and Figure 7). The data for the analysis was sourced from various factors such as the number and phytoplankton abundance, zooplankton density, Temperature, Salinity, pH, DO (dissolved oxygen), NO3 (Nitrate), PO4 (Phosphate), and DOM (Dissolved Oxygen Matter). Based on PCA analysis, important information that illustrates the correlation between the amount and abundance of phytoplankton with various environmental factors based on location and time of observation centered on three main axes (axes F1, F2 and F3). The explanation of each of the F1, F2 and F3 axes is $32.35 \%$ and $24.88 \%$ and $15.70 \%$, respectively. By only using the three main axes, the relationship between the number and abundance of phytoplankton with location and observation time can be explained as much as $72.93 \%$ of the total variance (Figure 7). 
Table 3. Results of measurements of average water quality and SE parameters during the study (SG: seagrass; S: sand; CR: coral reef; 0: start of study; 2,4 , and $6: 2^{\text {nd }}, 4^{\text {th }}$ and $6^{\text {th }}$ week).

\begin{tabular}{|c|c|c|c|c|c|c|c|}
\hline \multirow[b]{2}{*}{ Stasiun } & \multicolumn{7}{|l|}{ Parameter } \\
\hline & $\begin{array}{l}\text { Temperature } \\
\left({ }^{\circ} \mathrm{C}\right)\end{array}$ & $\begin{array}{l}\text { Salinity } \\
(\%)\end{array}$ & $\mathrm{pH}$ & $\begin{array}{l}\mathrm{DO} \\
(\mathrm{mg} / \mathrm{L})\end{array}$ & $\begin{array}{l}\begin{array}{l}\mathrm{NO} 3 \\
(\mathrm{mg} / \mathrm{L})\end{array} \\
\end{array}$ & $\begin{array}{l}\mathrm{PO} 4 \\
(\mathrm{mg} / \mathrm{L})\end{array}$ & $\begin{array}{l}\begin{array}{l}\text { DOM } \\
(\mathrm{mg} / \mathrm{L})\end{array} \\
\end{array}$ \\
\hline SG-0 & $30.46 \pm 0.20$ & $31.07 \pm 0.18$ & $8.42 \pm 0.03$ & $5.89 \pm 0.08$ & $0.033 \pm 0.005$ & $0.046 \pm 0.003$ & $33.73 \pm 1.12$ \\
\hline SG-2 & $30.53 \pm 0.68$ & $32.07 \pm 0.47$ & $8.29 \pm 0.01$ & $5.57 \pm 0.22$ & $0.036 \pm 0.010$ & $0.011 \pm 0.007$ & $46.73 \pm 1.31$ \\
\hline SG-4 & $30.23 \pm 0.17$ & $29.87 \pm 0.29$ & $7.58 \pm 0.03$ & $6.74 \pm 0.06$ & $0.056 \pm 0.015$ & $0.007 \pm 0.015$ & $51.33 \pm 3.63$ \\
\hline SG-6 & $30.11 \pm 0.10$ & $30.40 \pm 0.23$ & $7.52 \pm 0.01$ & $4.93 \pm 0.07$ & $0.030 \pm 0.009$ & $0.003 \pm 0.003$ & $40.95 \pm 1.52$ \\
\hline S-0 & $29.51 \pm 0.38$ & $29.94 \pm 0.31$ & $8.20 \pm 0.04$ & $5.46 \pm 0.22$ & $0.030 \pm 0.001$ & $0.067 \pm 0.003$ & $36.32 \pm 1.98$ \\
\hline$S-2$ & $30.79 \pm 0.15$ & $31.04 \pm 0.44$ & $7.97 \pm 0.16$ & $5.63 \pm 0.53$ & $0.031 \pm 0.010$ & $0.014 \pm 0.002$ & $43.41 \pm 3.09$ \\
\hline S-4 & $30.85 \pm 0.33$ & $29.65 \pm 0.08$ & $7.56 \pm 0.03$ & $5.30 \pm 0.61$ & $0.049 \pm 0.015$ & $0.008 \pm 0.001$ & $49.97 \pm 1.42$ \\
\hline$S=6$ & $29.89 \pm 1.02$ & $31.17 \pm 0.11$ & $7.55 \pm 0.01$ & $5.80 \pm 0.01$ & $0.033 \pm 0.009$ & $0.005 \pm 0.001$ & $38.82 \pm .070$ \\
\hline CR-0 & $29.19 \pm 0.76$ & $31.00 \pm 0.23$ & $8.32 \pm 0.01$ & $5.58 \pm 0.03$ & $0.033 \pm 0.006$ & $0.045 \pm 0.002$ & $34.51 \pm 2.47$ \\
\hline CR-2 & $30.51 \pm 0.04$ & $31.87 \pm 0.13$ & $7.93 \pm 0.01$ & $5.91 \pm 0.36$ & $0.027 \pm 0.008$ & $0.013 \pm 0.003$ & $42.72 \pm 1.02$ \\
\hline CR-4 & $29.49 \pm 0.09$ & $30.13 \pm 0.13$ & $7.49 \pm 0.01$ & $6.20 \pm 0.07$ & $0.047 \pm 0.015$ & $0.007 \pm 0.001$ & $47.88 \pm 2.71$ \\
\hline CR-6 & $29.99 \pm 0.02$ & $33.07 \pm 0.07$ & $7.48 \pm 0.01$ & $4.18 \pm 0.01$ & $0.027 \pm 0.009$ & $0.007 \pm 0.002$ & $40.15 \pm 1.13$ \\
\hline
\end{tabular}

Based on the results of the PCA analysis (Figure 7), there are three groups with several environmental factors as its characterizer. The first group was formed from initial observations, namely Seagrass (S-0), Coral Reef (CR-0), and Sand (S-0) characterized by low phytoplankton numbers and abundance under conditions of high $\mathrm{pH}$, salinity and $\mathrm{PO}_{4}$. The second group (observation time $\mathrm{W}-2$ ) are Seagrass-Week 2 (SG-2), Coral Reef-Week 2 (CR-2), Sand-Week 2 (S-
2) with a high number of species and abundance of phytoplankton and zooplankton and associated with high DO, $\mathrm{NO}_{3}, \mathrm{PO}_{4}$, and low DOM. Then, the third group (observation times W4 and W6) are SeagrassWeek 4 (SG-4), Coral Reef-Week 4 (CR-4), SandWeek 4 (S-4) which are characterized by a low number of species and abundance of phytoplankton and zooplankton with environmental characteristics of nitrate $\left(\mathrm{NO}_{3}\right)$, DOM, and high temperature.
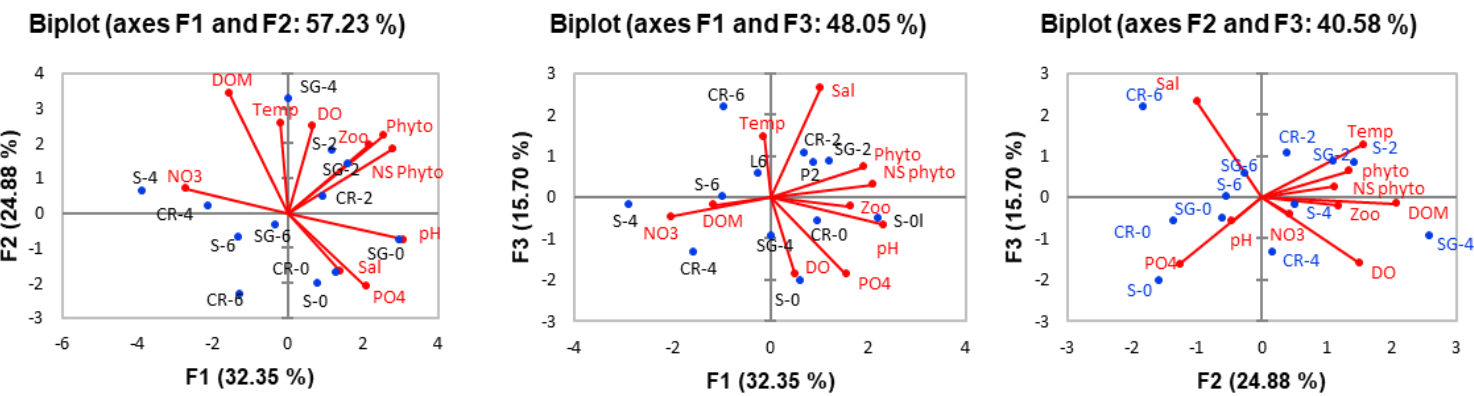

Figure 7. Distribution of location-time observations and environmental factors as well asabundance and richness of plankton species on three main axes (F1, F2, and F3) basedon principal component analysis (PCA)

The groups that are formed with several environmental factors as the identifier of each group. The groups in question are a representation of each observation time (initial observation time, W2, W4 and W6). The first group (initial observation time) was Seagrass (SG-0), Coral Reef (CR-0), and Sand (S-0) characterized by low phytoplankton numbers and abundance under conditions of high $\mathrm{pH}$, salinity and $\mathrm{PO}_{4}$. It was noted that the $\mathrm{pH}$ value corresponds to the requirements of phytoplankton with a range between 8.20-8.42 (Table $3)$. According to Hinga (2002), phytoplankton growth is detected faster in the $\mathrm{pH}$ range of 7-9. If the $\mathrm{pH}$ value is less than 7 and or more than 9, phytoplankton growth will be inhibited. Likewise, the range of salinity between 29.94-31.07\% (Table 3). Sachlan (1982) explains that salinity that exceeds $20 \mathrm{ppt}$ is in accordance with the growth and development of phytoplankton. Such salinity values cause phytoplankton to be more active in carrying out the process of photosynthesis. For nutrients, especially phosphorus is also in the range corresponding 
to phytoplankton (0.045-0.067 $\mathrm{mg} / \mathrm{L}$, Table 3). According to Effendi (2003), waters that have phosphate concentration ranges between 0.051-0.1 $\mathrm{mg} /$ Liter including fertile waters. In that range, phytoplankton grow well. Although environmental factors such as $\mathrm{pH}$, salinity and $\mathrm{PO}_{4}$ correspond to phytoplankton life, the amount and abundance are detected low at all locations (Seagrass, Coral Reef, and Sand). The reason for that is because phytoplankton are not optimal for growth and development because they are just in the beginning of the cultivation of seaweed (preliminary observation time).

Furthermore, the second group (W2 observation time) was Seagrass-Week 2 (SG-2), Coral Reef-Week 2 (CR$2)$, Sand-Week 2 (S-2). The high number and abundance of phytoplankton in zooplankton density conditions and high DO (dissolved oxygen) and $\mathrm{PO}_{4}$, and low DOM are characteristics in this group. The high number and abundance of phytoplankton is caused by these microorganisms absorbing nutrients especially phosphate as much as possible and then used in growth. In Table 3, it can be observed by looking at the phosphate concentration experiencing a decrease (0.011-0.014 $\mathrm{mg} / \mathrm{L})$. On the other hand, dense zooplankton as a result of the growth of phytoplankton are increasingly high. Similarly, the high concentration of dissolved oxygen. Increased amount and abundance of phytoplankton causes high oxygen production due to the large number of phytoplankton carrying out photosynthesis.

Then, the third group (observation times Week-4 and Week-6), namely Seagrass - Weeks 4 and 6 (SG-4 and SG-6), Coral Reefs - Weeks 4 and 6 (CR-4 and CR-6), Sand-Week 4 and 6 (S-4 and S-6) which are characterized by low phytoplankton abundance and abundance under zooplankton density conditions with Nitrate conditions $\left(\mathrm{NO}_{3}, \mathrm{PO}_{4}, \mathrm{DOM}\right.$, and high temperature and low DO, low zooplankton density which is one of the characteristics is a result of a decrease in phytoplankton abundance. The decrease in plankton abundance is considered to be due to an increase in temperature $\left(29.49-30.85^{\circ} \mathrm{C}\right.$, Table 3$)$. As a result, the amount and abundance of phytoplankton has decreased quite dramatically. This cause the concentration of nutrients $\left(\mathrm{NO}_{3}\right.$ and $\left.\mathrm{PO}_{4}\right)$ tend to increase because they are not absorbed by the phytoplankton.

\section{CONCLUSION}

In general, the impact of seaweed cultivation on the change pattern in the number and abundance of phytoplankton is observed to be the same in various areas of cultivation and observation time. However, the pattern of changes in the number and abundance of phytoplankton was found to differ between one area of cultivation and another in the area of temporal scale.

Seaweed cultivation at the beginning of the observation (2ndweek) was able to attract the number of species and abundance of phytoplankton to grow, however, itdecreased in the 4th and 6th week. Diversity index values at all locations and observation times are moderate, with high species uniformity without the dominance of a species of phytoplankton. Abundance and high phytoplankton species occur in week 2 in all areas of cultivation and are associated with high zooplankton and $\mathrm{DO}$ densities and high $\mathrm{NO}_{3}, \mathrm{PO}_{4}$, and DOM.

\section{REFERENCES}

Akib, A., M. Litaay, Ambeng, M. Asnady. 2015. The feasibility of water quality for the Eucheumacottoni cultivation area is based on physical, chemical and biological aspects in the Selayar Islands Regency. Jurnal Pesisir dan Laut Tropis.Vol 1 (1): 25-36.

Amin, S.A.,M.S. Parker, and E.V.Armbrust. 2012. Interactions between Diatoms and Bacteria. Microbiology andMolecularBiology Reviews. Vol76(3): 667-684.

APHA. 1989. Standard Methods for the Examination of Water and Waste Water Including Bottom Sediment and Sludges. 12-th ed. Amer. Publ. Health Associacion Inc., New York.

Apriliyanti, M.S. 2018. Identifikasi plankton dari kawasan budidaya rumput laut Kabupaten Bantaeng, Sulawesi Selatan dengan metode DNA Barcoding. Skripsi. Fakultas Pertanian Universitas Lampung, Bandar Lampung.

Arinardi, O.H., A.B. Sutomo,S.A. Yusuf, Trimaningsih, E. Asnaryantidan E. Riyono. 1997. The range of abundance and composition of predominant plankton in the waters of eastern Indonesia.Center for Research and Development of Oceanology.Indonesian Institute of Sciences.Jakarta. 140 pp.

Armbrust, E.V. 2012.The life of diatoms in the world's oceans.A Review.NATURE.Vol 459: 185-192.

Armbrust, E.V., and H.M. Galindo. 2001. Rapid Evolution of a Sexual Reproduction Gene in Centric Diatoms of the Genus Thalassiosira. Applied and Environmental Microbiology. Vol67(8): 3501-3513.

Bappenas, 2014a.The concept of main streaming ocean policy in the national development plan.Deputy for Natural Resources and Environment of the National Development Planning Agency. Jakarta. 360 pp.

Bappenas, 2014b.Strategic review of sustainable fisheries management.Directorate of Maritime Affairs and Fisheries, Ministry of National Development Planning-Bappenas. Jakarta. 120 pp. 
Burdames, Y., danE.L.A. Ngangi. 2014. Environmental Condition of Seaweed Culture at Arakan Village, South Minahasa Regency. Jurnal Budi daya Perairan.Vol 2 (3): 69 - 75.

Chepurnov,V.A., D.G. Mann, P. Von Dassow,P. Vanormelingen, J. Gillard, D.Inze,K. Sabbe, and W.Vyverman. 2008. In search of new tractablediatoms for experimental biology. BioEssays. Vol 30:692-702.

Collins, S., B. Rost, and T.A. Rynearson. 2014. Evolutionary potential of marine phytoplankton under ocean acidification. Evolutionary Applications.Vol7(1): 140-155.

Davis, G. C. 1955. The Marine and Freshwater Plankton. Michigan State University Press, USA.

Dwiyitno. 2011. Seaweed as a potential source of food fiber. Squalen. Vol6 (1): 9-17.

Effendi, H. 2003. Study water quality for resource management and aquatic environments.Penerbit Kanisius.Yogyakarta.

Faisal, R.S. Patadjai, dan Yusnaini. 2013. The Growth of Seaweed (Kappaphycusalvarezii) and Baronang Fish (Siganusguttatus) Cultivated Together in Bagan Tancap.Jurnal Mina LautIndonesia.Vol. 01 (01) : 104-111.

Hikmah. 2015. Strategy for developing seaweed commodity processing industry E. Cotonii to increase added value in the centers of the industrialization area. Jurnal Kebijakan Sosial Ekonomi Kelatan Perikanan.Vol 5 (1): 27-36.

Hinga, K.R. 2002.Effects of ph on coastal marine phytoplankton. A review.Marine ecology progress series.Vol. 238: 281-300.

Kadi. A. 2004.Potential seaweed in several Indonesian coastal waters.Oseana. XXIX (4): 25 - 36.

Krebs, C. J. 1989. Ecological methodology. Harper and Row Pub., New York. 745 p.

Kusumastanto, T. 2008. Policies and strategies to improve the competitiveness of Indonesian fishery products.Center for the study of coastal and marine resources,Bogor Agricultural University.66 hal.

Ludwig, J.A. and. J.F.Reynolds. 1988. Statistical Ecology: A Primer on Methods and Computing. John Wiley \& Sons. USA. 337pp.

Masson, C.F. 1981. Biology of fresh water Pollution.Longman.Inc, New York. 250 p.

Mochizuki, M.N, Saito M, Imai K, Nojiri Y. 2002.Seasonal changes in nutrients, chlorophyll-a, andthe phytoplankton assemblage of the western subarctic gyre in the
Pacific Ocean. Deep SeaResearch. 49(24): 5421-5439.

Neksidin. 2013. Study of water quality for seaweed cultivation (Kappaphycus alvarezii) in Teluk Kolono Waters, Konawe Selatan Regency. JurnalMina Laut Indonesia. Vol. 03 (12): 147 155.

Nontji, A. 2008.Marine Plankton.YayasanObor Indonesia. $331 \mathrm{pp}$.

Odum, E. P. 1998. Fundamentals of Ecology (Interpreting: Samingan, T.).Edisi Ketiga. Universitas Gadja Mada Press, Yogyakarta.

Pandiyarajan.R.S.,

P.S.Shenai-Tirodkar, M.Ayajuddinand Z.A. Ansari. 2014. Distribution, abundance and diversity of phytoplankton in the inshore waters of Nizampatnam, South East coast of India. Indian Journal of Geo-Marine Sciences.Vol. 43(3) :348-356.

Priono, B. 2013.Seaweed cultivation in an effort to increase fisheries industrialization. Media Akuakultur.Vol 8 (1): 1-8.

Putri,D.,W.D. Sayekti, dan N. Rosanti. 2014. Analysis of income and development strategies for seaweed cultivation in Pahawang Island, Punduh Pidada District, Pesawaran Regency. JIIA, Vol2 (1): 56-63.

Rachbini, D.J., B.Arifin, A.E.Yustika,E. Hartati, E.Listiyanto, A.H.Firdaus, A.P.G.Talattov, danI. Abdullah. 2011. Outlook Industri 2012:Strategy of accelerating and expanding agro-industry. Ministry of Industry of the Republic of Indonesia.197 pp.

Radulovich, R.,S. Umanzor, R. Cabrera, and R. Mata. 2015. Tropical seaweeds for human food, their cultivation and its effect on biodiversity enrichment. Aquaculture (436) 40-46.

Sachlan, M. 1982. Planktonologi. Correspondence Course Centre. Directorate General of Fisheries, Ministry of Agriculture, Jakarta.

Sievanen, L., Crawford, B., Pollnac, R. \& Lowe, C. 2005.Weeding through assumptions of livelihood approaches in ICM: Seaweed farming in the Philippines and Indonesia.Ocean and Coastal Management. 48(3-6): 297-313.

Syafiuddin. 2008.Relationship between characteristics and competence of seaweed farmers (Eucheuma spp.) In three districts in South Sulawesi Province. Disertation. Postgraduate School. Bogor Agricultural University, Bogor.

Syarqawi, M., S.A. El Rahimi,danI. Rusydi. 2017.The Influence of Seaweed Bag on The Growth of Seaweed (Eucheuma cottoni) in The Waters of Simeulue Regency. Jurnal Ilmiah Mahasiswa 
Kelautan dan Perikanan Unsyiah.Vol.2 (2): 277285.

Talib, A. 2018.Opportunities and challenges of the fisheries processing technology industry in supporting the realization of LumbungIkan Nasional (LIN) in North Maluku di Maluku Utara. Jurnal Agribisnis Perikanan. Vol 11(1): 19-27.

Tomas, C.R. 1997. Identifying marine phytoplankton. Academic Press. San Diego California.
Wagimandan M. Ainuri. 2015. Building integrated policies and strategies to improve the function of Seaweed in Buton, Southeast Sulawesi. Prosiding Seminar Agroindustri dan Lokakarya Nasional, FKPT-TPI.UniversitasTrunojoyo Madura, Madura.

Yamaji, C.S. 1979. Illustration of the Marine Plankton of Japan.Hoikiska Publ. Co. Ltd, Japan. 